doi: $10.15503 /$ jecs2021.1.429.444

\title{
FORMS OF PREJUDICE ABOUT CHRISTIANS AND SOCIAL COHESION BETWEEN UNIVERSITY STUDENTS IN SLOVAKIA: MEDIA AS AN ESSENTIAL PART OF THE ISSUE
}

\author{
HEDVIGA TKÁČOVÁ \\ Department of Philosophy and Religious Studies, \\ Faculty of humanities at University in Zilina, Zilina, Slovakia \\ Univerzitná 1, 01001 Zilina, Slovak Republic \\ E-mail address: hedwiga.tkacova@gmail.com \\ ORCID ID: https://orcid.org/0000-0003-3062-2284
}

\begin{abstract}
Aim. The subject of our interest is to research the forms of prejudice about Christians among university students. Part of the research focuses on the question of the forms of prejudices of the research group in relation to religious classmates - peers and part of on significant influence of media on the negative perception of Christianity in the society. The reflection of the findings is a consideration of the decline in social cohesion due to (1) the existence of prejudices in the university environment in Slovakia, and (2) the often negative media presentation of Christian religion in the Slovak media.

Concept. The starting point of the issue is the research into the forms of prejudice and the potential for social exclusion of young people due to the existence of prejudice in the university environment. The need for this kind of research and reasoning arises from growing fears and the strengthening of phobias that accumulate within the groups we observe.

Results and conclusion. The reflection of the findings is a consideration of the decline in social cohesion due to (1) the existence of prejudices in the university environment in Slovakia, and (2) the often negative media presentation of Christian religion in the Slovak media.

Cognitive value. Qualitative statements confirm the decline in social cohesion among peers due to religious diversity. We consider the presence of religious prejudices as an urgent call for such forms of education that would effectively contribute to the acceptance of cultural and religious diversity in society and to the promotion of social cohesion in the university environment.
\end{abstract}

Key words: prejudice, social cohesion, university students, diversity, media.

\section{INTRODUCTION}

hildren and young people receive information about groups in society through authorities such as parents, teachers and peers. OksanaS. Rybak (2018) reminds 
that "the set of values absorbed by an individual in the course of socialization is "translated" to him / her by the society itself as well" (p. 12). Already at the age of four, children gain a preference in relation to members of their own group; at the age of seven, they already know how to consciously express a negative attitude towards what they consider different from themselves and "theirs" (Langmeier \& Krejčiřová, 1998). As part of human development, there is a short-term decline in prejudice in subsequent years and, conversely, there is an increase in tolerance, which is related to the theory of cognitive development - according to experts, children and young people are better able to understand the other person's situation and have a greater effort to focus on morality (Piaget \& Inhelder, 1993; Žilínek, 1997; Fontana, 2003; Leslie, Knobe, \& Cohen, 2006; Vacek, 2008; Tolnay, 2016).

According to Edgar Josef Korherr or Mannheim, a young person has several opinions he has taken over from his parents and the environment, but it is during adolescence that he / she is re-evaluating these opinions and attitudes (Korherr, 1996, pp. 151-153; Mannheim, 2007, p. 13). Moreover, the adolescent already consciously rejects the uncritical adoption of the opinions of others to shape his own worldview, even on religious and moral issues. According to Michal Stríženec, it is also a period of religious discord, which is accompanied by many intellectual, motivational, and emotional conflicts that the individual has with himself and his surroundings (Stríženec, 2001, p. 64). In short, our research sample of respondents represents a period of significant holistic personality formation, i.e., receiving or rejection of the opinions of others, including the orientation of opinion towards human, opinion or religious diversity. In the last year at the university, the educational process in its institutional form is completed. Graduates enter working life not only with their individual "package" of expectations and hopes, but also with knowledge, values, and attitudes. Prejudices acquired so far are also part of this "package".

What is the role of higher education in accepting, preserving, or eliminating prejudice? The starting point for this question is the fact that university students represent a group of young people in the final period of adolescence. According to experts, this period is the last chance for a complete correction of social (individual and collective) intolerance of the individual (Allport, 1954; Hinton, 2000). This was also confirmed by a sociological survey focused on the occurrence of racism, xenophobia and intolerance in Czech schools; it turned out that the development of multicultural attitudes is not related to gender, but to age and personal maturity (Šišková, 1998). Michal Vašečka (2009) also confirmed age differences in the assessment of social diversity in favour of younger research participants (age 18-34); compared to older participants (over the age of 55), they were much more open and positive towards social diversity. Finally, knowledge from developmental psychology recalls the limited ability of man to form in adulthood. In general, adults already have more deep-rooted attitudes, are more difficult to work with and the change is minor. In short, it is mainly children and young people (especially at the time of their institutional education) who can change their thinking, phenomena, and behaviour flexibly; if they perceive diversity and are led to its positive evaluation from early childhood, they will come naturally into adulthood. 
Graeme Burton and Jan Jirák characterize prejudices as deliberately negative attitudes towards others, which arise and develop based on subjective reasons (not for objective reasons, such as lack of information) (Burton \& Jirák, 2003, pp. 196-197). According to Ján Grác, prejudice is always a negative stereotypical position of an individual against someone or something, which often leads to the exclusion of the individual; at the same time, the author characterizes prejudice as "an intense attitude or opinion or even a group of interconnected attitudes that resist change for a long time" (Grác, 1985, p. 146). Anthony Giddens (1999) classifies prejudice as the driving force of stereotypical reasoning (p. 231). Prejudice can also be aptly described through its anglicism; in the past, the term meant what is now the English term prejudge, i.e., condemn in advance.

The exclusion of an individual from the group is preceded by several phenomena. One is its negative classification by other individuals or communities based on an initial classification that divides people into groups and assigns positive and negative values to those people. In general, we are talking about the so-called stereotyping. Experts often refer to stereotypes and prejudices as equal concepts, and we also come across opinions where the two concepts are in a kind of conditioned relationship. According to social psychology, stereotypes are linked to prejudice, but it is not the same (Allport, 1954; Giddens, 1999; Hinton, 2000). Jarmila Lajčáková, Elena Gallová-Kriglerová, Jana Kadlečíková, Zuzana Balážová and Alena Chudžíková (2017) point out that prejudice is a more extreme form of stereotyping, as it activates when confronted with diversity, i.e., member or members of a different group. Prejudices often form a reaction unknowingly, that is, not purposefully and thoughtfully. Therefore authors characterize prejudice as an attitude, emotion or behaviour, which is also characterized by unconscious negativity and antipathy (p. 8). Aleksander Kobylarek (2016) also draws attention to this danger when he says that even temporary emotions (for example resentment) can in unfavourable circumstances escalate into permanent emotions (i.e. permanent resentment), which is more difficult to alleviate" (p. 5; p. 7). The Open Society Foundation in Slovakia points out that it is precisely the unconscious use of prejudices, often precisely in unfavourable circumstances, that discriminatory behaviour can occur in society and, in practice, even discretionary use of prejudice really lead to discriminatory behaviour (Open Society Foundation, 2016, p. 34).

According to experts (Allport, 1954; Šišková, 1998; Vašečka, 2009; Vašečka, 2013; Kopčanová, Kopányiová \& Smiková, 2016; and others), prejudice is based on a strong identification with one's own group and emphasizes the contradictions between one's own and another's group. Prejudices thus contribute to the view of the world in two opposite terms - "we" on the one hand and "they" (the others; different; foreigners, etc.) on the other. The subject of both positions is the question of "what does" and "what it is like" the second group as opposed to "what it does" and "what it is like" our group. However, we must emphasize that "they" are not always unknown individuals to us, i.e., people we do not know very well or do not know at all. Sociologist Bauman recalls that those we perceive as "they" are often "very well known to us" (Bauman 1996, p. 61). 
According to Jana Plichtová and Tatiana Podolinská (RTVS, 2017), however, the view of "we" and "they" contains its own emotion. In the case of prejudice, it is always a negative emotion (usually negative in the case of a stereotype, note) and at the same time it carries with it the behaviour that results from this point of view and emotions. Tatjana Šišková (1998) also draws attention to distrust and hostility towards different individuals and groups, which arises because of strong identification with her own group. Consideration, which is characterized by an individual's tendency to prejudice, includes not only a tendency to discriminate negatively, but, in the words of Professor Jana Plichtová, director of the Institute of Ethnology of the Slovak Academy of Sciences, "a hidden or even obvious tendency to harm" (RTVS, 2017).

We can see that in addition to the attitude side (directed against individuals and whole categories of people), prejudices also include aspects that lead to discriminatory attitudes and intolerant/violent behaviour. The fact remains that such manifestations occur in Europe and in the world also because of the religious diversity that interests us in the article. We ask ourselves whether prejudices about Christians are applied in Slovakia and what forms of prejudices about Christians prevail among young university students. The question arises despite the fact that Slovakia is considered a Christian country; for example, on the basis of several relevant researches of values present in the Slovak public (Religion 1998; Bunčák, 2001;Krivý, 2001; EVS, 2008; World Research of Values, 2008; Grešková, 2010). According to the last census (May 2011), there are $62 \%$ Catholics, almost $6 \%$ Lutherans and almost $4 \%$ Greek Catholics in Slovakia, which represents a significant majority of Christians compared to nonChristians, i.e. other religious and non-religious groups (Slovak Academy of Sciences, 2011; Ministry of Culture of the Slovak Republic and Church Department, 2017; Statistical Office of the Slovak Republic, 2019). There is probability that most Slovaks feel comfortable with Christian perspective for all levels of individual existence; i.e. existence towards eternity (Máhrik, Vasbieva, Králik, \& Kondrla, 2020); i.e. existence pervaded with Christocentric radical obedience to God, as for example Kierkegaard understood (Pavlíková \& Žalec, 2019).

As confirmed by experts (Hargašová, 1996;Šišková, 1998; Hofreiter, 2002; Kvasničková, 2005; Dojčár, 2012; Grešková, 2013; Kugler, 2017; and others), Slovak Christians do not encounter as much intolerance and discrimination as we see in advanced countries of Europe (not to mention third world countries, where Christians are even persecuted for their religious beliefs). On the other hand, this does not mean that Slovak Christians do not perceive a whole range of latent forms of intolerance - we mean, for example, condemnation for public and social expressions of faith (or refusal to understand faith only as a matter of individual conscience), derogatory stereotypes, attacks on the Church, ridicule of Christian ethical norms and values (i.e. issues of ethics, human life, family, marriage, sexuality), etc.

The Slovak media also have a significant influence on the negative perception of Christianity in the society. They present contents with elements of aggressive secularism, slander of Christians, and strong negative attitudes towards the Church (Mikulová, 2018;Marec, 2020).Media can promote, support and educate, 
or indoctrinate and spread false truths, for example through reporting stories in a biased way; through focusing on the more extreme aspects rather than the Christian community as a whole; through giving a one-sided image of religion or spreading a message of bigotry and hate about particular groups of people and so on. In response to negative media content, Christians in Slovakia are therefore facing a high risk of rejection for their religious self-disclosure. Such a response is also confirmed by foreign research. Piotr S. Bobkowski and Sriram Kalyanaraman argue about negative stereotyping increased toward Christians who disclosed more about their religious beliefs and practices (Bobkowski \& Kalyanaraman, 2010); other research confirmed that Christians avoid self-disclosure in order to escape the sociopolitical stereotypes (Putnam \& Campbell, 2010); or they believe that Christian values are unfavourably targeted by social opposition (Castelli, 2007) and so on. The media regularly portrays Christians as intolerant, militant, and racist (Kerr \& Moy, 2002). Media reporting that some individuals have a different group identity than the social majority can be media-attractive, but destructive to communication and relationships between people. In particular, criticism and negative portrayals of Christians in the media (including the characteristics of this group, attitude toward Church, etc.) can then provoke intergroup anxiety. This in turn has the effect of increasing prejudice in real communities (Islam \& Hewstone, 1993; Stephan \& Stephan, 2000).

For the above reasons, we see the need for research into the existence and forms of prejudice in the university environment as welcome and necessary. Our effort will be to approach the forms of prejudices of university students about Christians in general and especially the forms of prejudices about Christians who are peers of the studied students. The nature of the research turns out to be topical, as various cultural, racial, and religious prejudices predominate in Slovak society (Institute of Sociology of the Slovak Academy of Sciences, http:/ / www.sociologia.sav.sk/old/evs.html; Valach, 2000;Krivý, 2001; Kamenec, 2005; Tižík, 2006; Vašečka, 2009; Vašečka \& Koštál, 2009;Gyárfášová, 2010; Tižík, 2011; Grešková, 2013; Vašečka, 2013; Ministry of the Interior of the Slovak Republic, 2014; and others). The need for this kind of research and reasoning also arose based on the need to build human virtues (Valčo, Valčová, Kardis, \& Slivka, 2019; Žalec \& Pavlíková, 2019; Martín, Rojas, \& Králik, 2020; Vymetalova-Hrabakova, Kondrla, Vlasova, Dmitrichenkova, \& Pashanova, 2020), as well as civic virtues (Králik, Lenovský, \& Pavlikova, 2018; Roubalová, Králik, Slivka, \& Tavilla, 2018; Slivka, 2018) as opposed to fears, scepticism, suspicion and the strengthening of phobias that accumulate in Slovakia within the groups we monitor (Hargašová, 1995; Hargašová, 1996; Poláková, 2000; Bunčák, 2001; Vlach, 2006; Cenker, 2010).

\section{METHODOLOGY}

The research group consists of 210 adolescent students of the last year of fulltime study, who study at three universities in Slovakia. The field phase of the research took place in the period from November 2019 to June 2020 (Table 1). 
Table 1

The research group

The characteristics of The research group

the research group

Type of study

University with a technical focus

(210 respondents)

\begin{tabular}{|c|c|c|c|}
\hline & \multicolumn{2}{|c|}{ University with a humanity focus } & 40.47 \% (85 resp.) \\
\hline & Univer & with mixed type of study & $25.71 \%$ (54 resp.) \\
\hline \multirow[t]{2}{*}{ Sex } & 1. & Men & $45.23 \%$ (95 resp.) \\
\hline & 2. & Women & $54.76 \%$ (115 resp.) \\
\hline
\end{tabular}

Source: own research

The main research method, the questionnaire, is a combination of quantitative and qualitative questions. The questionnaire was designed to enable the acquisition of data and data on the deeper processes and attitudes of the research sample (see Gavora, 2007, p. 169); the questionnaire contained openended questions, which we categorized.

Our goal is to find out:

$1^{\text {st }}$ Partial objective: Forms of prejudices of the research group in relation to Christians in Slovakia,

$2^{\text {nd }}$ Partial objective: Forms of prejudices of the research group in relation to their faithful peers.

$3^{\text {rd }}$ Partial objective: The potential for social exclusion of young Christians due to the existence of prejudice in the university environment.

The research objectives were formulated in the form of three research questions (Table 2).

Table 2

Quantitative research - research questions

Quantitative research - research questions

1st research question: What are the most common prejudices about Christians in Slovakia from the point of view of researched university students?

2nd research question: What are the most common prejudices about young Christians in the environment of Slovak universities?

3rd research question: Is there a potential for social exclusion of young Christians due to the existence of prejudice in the university environment?

Research method

More than 800 students of the last year of study at the

Questionnaire second level at three universities in Slovakia were addressed.

Return of the questionnaire: the final 210 respondents.

Source: own research 


\section{RESULTS}

Research into the forms of prejudices about Christians and young Christians in Slovakia in a research group of Slovak university students provided answers to three research questions:

1 What are the most common prejudices about Christians in Slovakia from the point of view of the studied university students? (1 ${ }^{\text {st }}$ research question)

Table 3

The most common prejudices about Christians in Slovakia

Prejudices about Examples of respondents' answers
Christians Christians

Hypocrisy
Affaires and scandals
Power and economic
interests of the
Church
Condemnation and
moralizing

Unattractive life

Obscurantism

Irrationality

Religious violence

Neutral attitude

Other
They talk about love, and yet they act unkindly; They point to the rules of faith, and they do not live by them; They go to church only to be seen by other people and so on.

Failure to address or completely ignore the crimes of paedophilia; Cooperation of priests with the State Security during communism, and so on.

The Church longs for power; The Church declares modesty but lives in luxury and asks more and so on.

Condemnation of unbelievers; If something is not according to their rules, they (Christians) are intolerant; Violent coercion of one's own opinions to fanaticism, etc.

They deny man all that is nice and pleasant; They force a person to follow the rules and live in constant renunciation, etc.

Christians blindly follow the outdated orders of the pastors; They live in obscurantism as a church tradition and the like.

Religion is just a myth; Christians believe in delusion (the saint was no one); Christians are a naive flock of sheep and so on.

$67.61 \% / 142$

$46.66 \%$ / 98

$33.80 \%$ / 71

$33.33 \% / 70$ The attitude of the church towards the Jews during the Second World War, etc.

Nothing bothers me about Christians.

I am especially bothered by Catholics; God does not exist and so on. 
We categorized the most frequent answers of 210 respondents into ten categories. Eight of them can be described as prejudices: hypocrisy of Christians $(75.23 \%)$, affaires and scandals (of the majority) of church leaders $(67.61 \%)$, power and economic interests of the Church (53.33\%), condemnation and moralization of unbelievers by Christians (51.90\%), unattractive life of Christians (51.42\%), obscurantism of Christians (46.66\%), irrationality of Christians (33.80\%), religious violence (33.33\%). The most numerous statements of the respondents in relation to Christians and Christianity in Slovakia are closed by the category expressing the neutral attitude of the respondents towards Christians - the answer to nothing bothers me about Christians stated $19.52 \%$ of respondents. The category "other" represents only a low of $9.04 \%$. The difference in the findings between the examined men and women was statistically insignificant. The difference of findings based on the type of study of the surveyed respondents was not confirmed either. As these were open-ended questions from the questionnaire, respondents were able to provide several answers; therefore, the sum of the responses in the following table does not correspond to the total sum of $100 \%$ (Table 3).

2 What are the most common prejudices about young Christians in the environment of Slovak universities? ( $2^{\text {nd }}$ research question)

The second research question followed the attitude of respondents towards Christian peers in the environment of the surveyed universities. The evaluation was marked by personal experiences and examples, which the researched university students presented in the open questions of the questionnaire. We categorized the most common answers into eight categories; six of them can be interpreted as prejudices. In the research group, the rate of measured values in the identified prejudices about Christians - peers is significantly lower (\%) than the values (\%) in the categories of prejudices about Christians in general (see: Table 3 and Table 4).

Negative answers in the questionnaire relate to those individuals who, from the point of view of the researched students, show signs of an unattractive lifestyle $(27.61 \%)$, adhere to strict morals $(22.85 \%)$, are perceived as hypocritical $(21.90 \%)$, give excessive emphasis on their faith $(12.38 \%)$, they present opinions (resulting from faith) that respondents describe as "incomprehensible" $(11.90 \%)$ and are too polite and respectful $(9.04 \%)$.We noticed a neutral attitude (nothing bothered me on Christians - peers) in 31.90\% of respondents, which is the most common answer. In the other category, $5.23 \%$ of responses were recorded. Even in this part of the research, we did not notice a statistically significant difference between the examined men and women. The difference in groups based on the type of study (technical, humanities and mixed, note) was also not confirmed. As respondents had several options to answer a specific questionnaire, the sum in the following table does not correspond to $100 \%$ (Table 4). 
Table 4

The most common prejudices about Christians - peers

Prejudices about Examples of respondents' answers

Christians - peers

Findings

\% / num-

ber of re-

spondents)

They lead an unat- They do not go to a disco; They have (Christian) 27.61\% / 58

tractive way of life rules for everything; They do not drink or smoke, etc.

They adhere to

strict morals

They will not advise during the written exam;

They are for sex after marriage; They do not cheat and do not depreciate, etc.

They are hypocriti- They tell others what they should do and do not cal do themselves; They judge a person by going to church and behaving worse than he is; They think that they can wash away their sins with confession and then repeat them with a smile and so on.

They emphasize They are often exaggerated; They go to Mass evetheir faith too much ry Sunday and on some normal days, etc.

They have "incomprehensible" opinions (resulting from their faith)

They are unnaturally polite and respectful They condemn yoga, reiki, homeopathy, healers, $11.90 \%$ / 25 $12.38 \%$ / 26 etc.

They condemn slander; They cannot make fun of others; They cannot stand up for themselves and so on.

Neutral attitude Nothing bothers me

Other

They think they are something more; They partici-

$5.23 \% / 11$

Source: own research

3 Is there a potential for social exclusion of young Christians due to the existence of prejudice in the university environment? ( $3^{\text {rd }}$ research question)

The qualitative dimension of our findings suggests that social cohesion is declining among students in the school environment due to dual diversity:

Respondents negatively value peer believers: for example, the Christian rules that their fellow believers follow, the hypocrisy of Christians, the emphasis on faith or incomprehensible opinions, and so on.

b) Respondents describe their unfulfilled expectations, resp. The "shortcomings" they read to their peers.

The research identified the following unfulfilled expectations of the studied university students: young Christians (peers) do not go to the disco (24 answers); They will not advise during the written exam (21 answers); They are for sex after marriage (20 answers); They have (Christian) rules for everything (21 answers); Preach to others, what they should do and not do so themselves (19 replies); They condemn yoga (17 answers); They often overdo it (17 answers), etc. 


\section{CONCLUSIONS}

The study presented the theoretical basis of the issue of applying prejudice and own research. The results of the study provide several findings that can be divided into three levels corresponding to three research questions:

1. What are the most common prejudices about Christians in Slovakia from the point of view of the studied university students?

The existence of prejudices in the examined adolescents in relation to Christians was confirmed through eight categories. The researched students associate Christians with hypocrisy (75.23\%), affairs and scandals (of the majority) of church leaders $(67.61 \%)$ and with the power and economic interests of the Church $(53.33 \%)$. The three most common statements continue with a negative assessment of the condemnation and moralization of unbelievers by believers in Slovakia (51.90\%). In other categories - the unattractive life of Christians $(51.42 \%)$, obscurantism $(46.66 \%)$ and the irrationality of Christians $(33.80 \%)-$ respondents give the most examples and their own observations and experiences. The category of religious violence (33.33\%) concludes the most numerous statements of respondents in relation to Christians and Christianity in Slovakia. In the category "other" there were only 5.23\% of answers. It is also worth mentioning the least represented category, expressing the neutral attitude of the respondents towards Christians; the statement "nothing bothers me" was given by approximately one in five respondents (19.52\%); compared to the most numerous category (hypocrisy $-75.23 \%$ ), this is a relatively significant difference to the detriment of the positive evaluation of Christians in the research group examined. There were no statistical differences between men and women in the results. The percentage difference of responses in groups based on the type of study of respondents (technical, human and mixed) was not confirmed either.

We believe that exposing tendencies to use prejudices against Christians in general may be a necessary impetus for further and more concrete education of university students on the issue of cultural and religious diversity in society. The results also call for preventive measures that would respond to the presence of intolerance among young university students.

2. What are the most common prejudices about young Christians in the environment of Slovak universities?

The forms of prejudice of the examined adolescents in relation to their peers were confirmed through six categories. Christian peers are associated with unattractive lifestyle $(27.61 \%)$, strict morals $(22.85 \%)$, hypocrisy $(21.90 \%)$, too much emphasis on faith (12.38\%), incomprehensible opinions (resulting from faith $(11.90 \%)$ and with unnatural decency and respect $(9.04 \%)$. The other category represented only $5.23 \%$ of responses. Most respondents said they did not mind young Christian peers (31.90\%).

The evaluated young Christians are considered by the research group to be different for religious reasons: as believers, according to the respondents, they lead an unattractive way of life; they adhere to strict morals; present incom- 
prehensible (i.e., influenced by faith or influenced by the Church) opinions, etc. We consider it negative that young Christians are often described in the research group as humanly different: according to the respondents, they place too much emphasis on their faith; they are hypocritical; they are too polite and respectful, etc.

The qualitative dimension of the answers obtained suggests that in certain situations in the school environment, social cohesion is declining among students, as most respondents openly name the unfulfilled expectations (possibly "shortcomings") they perceive among young Christians. On the positive side, we recorded only low values (up to $27.61 \%$ ) in the identified categories.

Even in comparison with the evaluation of Christians in Slovakia (1st research question), Christian peers in the research group have a significantly lower percentage of negative answers (2nd research question), which can be evaluated positively. We see this, for example, when comparing the category of hypocrisy that occurred in both groups. In the evaluation of Christians in Slovakia, up to $75.23 \%$ (i.e. 158) of respondents stated hypocrisy, but only $21.90 \%$ (i.e. 46) of respondents stated hypocrisy in relation to Christian peers; we also record relatively low values (in \%) in other categories. Moreover, a neutral attitude (i.e. the answer "nothing bothers me on Christian peers") was the most common answer; we recorded it in approximately every third respondent $(31.90 \%)$. In short, it can be said that the evaluation of peers in the research group shows significantly less negativity than the evaluation of Christians in general. However, we cannot be satisfied with the results so easily. Experts on the issue of the existence of prejudices in social groups point out that unfulfilled expectations and the present negativity can stimulate negative emotions in our research group, which are an important source for the emergence of prejudices and their further application.

A positive finding of the research is the explicit fact that in the research group of young university students, the personal experience of individuals who consider themselves (for various reasons) to be different proves to be a suitable way to suppress prejudices. Our research thus joins a number of experts who are also convinced of the urgent need to strengthen interactions between different people (Omeri, Malcolm,\& Ahern, 2003; Stockdale, 2004; Sibley \& Duckitt, 2008; Polonský \& Novotný, 2011; Gay, 2013; Mesková, 2018; Mutlu, 2020). Although mutual expectations between people are not always fulfilled, the personal experience of (also) diverse individuals seems to be one of the appropriate options to avoid a more significant decline in social cohesion in the school environment (due to social bias and prejudice), but also prejudice and their consequences. In addition, the school environment opens up an ideal space for the implementation of activities that are an alternative to the frequent negative image of Christianity in the media. We are thinking of school activities which, in the context of personal experience of individuals, strengthen respect for diversity and variability, increase students' knowledge and skills (for example in the field of human rights and intercultural dialogue), or support initiatives aimed at cooperation and solidarity. 
3. Is there a potential for social exclusion of young Christians due to the existence of prejudice in the university environment? $\left(3^{\text {rd }}\right.$ research question)

Further research would be needed to answer the third research question reliably. Despite this unsolved conundrum, the benefit of the research is not only the identified forms of prejudices about Christians and young Christians in Slovakia, but also statements of a qualitative nature, which in the research file indicate declining social cohesion and thus the probability of applying prejudices about Christians in Slovakia and prejudices about peers college and among them. The research further confirmed that the decline in social cohesion in the relationship between students and their religious peers is not only conditioned by the prejudices themselves (we identified 6 categories in the research, i.e. forms of prejudice about young Christians), but also by dual diversity, which a) supports existing prejudices, b) apparently has the potential to encourage the emergence of new prejudices.

In the context of qualitative findings of our research, we see as a problem the fact that some of the researched students perceive diversity as a "problem" and not as an opportunity to support learning, personal growth, cooperation, mutual enrichment, etc. The existence of prejudices in higher education thus also contributes to the creation of barriers in learning (and not only in learning). Their gradual overcoming is certainly primarily in the competence of a particular school. We therefore perceive the need of other prevention mechanisms in the research groups. Welcome and necessary may be the implementation of media education in cross-sectional school subjects. In addition to practical training in the use of media (i.e. learning-by-doing, practice learning), media education also represents the necessary critical-reflective approach to the media; media education represents formal education about the media, media effects, ethics in the media, critical thinking, manipulation in the media, etc. The practical and critical-reflective approach leads to the strengthening of media literacy, to greater critical thinking and to the individual's resistance to the media and their (often stereotypical) manipulation. Through media education, the individual learns to deal with criticism and negative portrayal of individuals and entire groups in the media. Media education can thus have a positive effect on potential intergroup anxiety and the level of application of prejudice in real communities (Islam \& Hewstone, 1993; Stephan \& Stephan, 2000).

Finally, the prevention with an emphasis on preventing the emergence of prejudices and eliminating prejudices in the event that they occur in the school environment is proving to be a necessary condition for a successful educational effect of the entire educational process. They lead young people not only to accept another person despite their differences (the so-called inclusive approach), but also to take responsibility for their actions and the actions of the group and community of which young people are a part (i.e. social responsibility). In addition, the elimination of prejudices and the consequent respect for cultural diversity contributes to the higher inclusion of excluded individuals and thus to the promotion of their self-esteem, values, interests, motivation 
and, last but not least, a sense of security. If this is not the case, the potential for social exclusion of young Christians (and not only Christians) as a result of the existence of prejudice naturally grows in the university environment.

\section{REFERENCES}

[1] Allport, G. W. (1954). The nature of prejudice. Cambridge, Massachusetts: Addison-Wesley publishing company.

[2] Bauman, Z. (1996). Mysletsociologicky. Netradičníuvedení do sociologie [Think sociologically. Unconventional introduction to sociology], Praha: Slon.

[3] Bobkowski, P. \& Kalyanaraman, S. (2010). Effects of online Christian self-disclosure on impression formation. Journal for the Scientific Study of Religion, 49(3), 456-476.doi: 10.1111/j.1468-5906.2010.01522.x.

[4] Bunčák, J. (2001). Religiozita na Slovensku: stredoeurópsky rámec[Religiosity in Slovakia: Central European Framework], Sociológia, 33(1), 47-69.

[5] Burton, G.\&Jirák, J. (2003). Úvod do studiamédiú [Introduction to media studies], Brno: Barrister \& Principal.

[6] Castelli, E. (2007). "Persecution complexes: Identity politics and the 'War on Christians.'” A Journal of Feminist Cultural Studies, 18(3), 152-180.

[7] Cenker, M. (2010). Moslimskí migranti v Bratislave [Muslim migrants in Bratislava], Sociológia, 42(3), 213-236.

[8] Dojčár, M. (2012). Problém globálneho spolužitia: antropologické východisko[The problem of global coexistence: an anthropological basis], Bratislava: Veda.

[9] EVS. (1999). Výskum európskych hodnôt [Research on European values]. Retrieved November 13, 2020, from http://sasd.sav.sk/sk/data_katalog_abs.php?id=sasd_1999002.

[10] EVS. (2008). Výskum európskych hodnôt [Research on European values]. Retrieved November 13, 2020, from http://sasd.sav.sk/sk/data_katalog_abs.php?id=sasd_2008001.

[11] Fontana, D. (2003). Psychologie ve školni praxi [Psychology in schoolpractice], Praha: Portál.

[12] Gavora, P. (2007). Sprievodca metodológiou kvalitatívneho výskumu [Guide to qualitative research methodology], Bratislava: Univerzita Komenského v Bratislave.

[13] Gay, G. (2013). Teaching To and Through Cultural Diversity. Curriculum Inquiry, 43(1), 48-70 https://doi.org/10.1111/curi.12002.

[14] Giddens, A. (1999). Sociologie [Sociology], Praha: Argo.

[15] Grác, J. (1985). Persuázia: Ovplyoňovanie človeka človekom [Persuasion: Influencing man by man], Martin: Osveta.

[16] Grešková, L. (2010). Societal Reactions to New Religious Movements in Slovakia. In: D. Hall and R. Smoczynski (Eds.), New Religious movements and conflict, (pp. 29-95). Warsaw: IFiS Publisher.

[17] Grešková, L. (2013). Spoločenské reakcie na náboženské menšiny [Social responses to religious minorities]. In: O. Prostredník (Ed.), Cudzie nechceme, svoje si nedáme? Prekonávanie xenofóbie a antisemitizmu v náboženských textoch a praxi, (pp. 45-62). Bratislava: Univerzita Komenského v Bratislave.

[18] Gyárfášová, O., \& Sekulová, M. (2010). Diskriminácia a viacnásobná diskriminácia: Pohl'ady verejnosti na diskrimináciu, rovnost' a rovné zaobchádzanie. Pracovný zošit [Discrimination and multiple discrimination: public perspectives on discrimination, equality and equal treatment. Workbook], Bratislava: Inštitút pre verejné otázky.

[19] Hargašová, M. (1995). Tolerancia a intolerancia mládeže SR v skupinovom a interpersonálnom kontexte [Tolerance and intolerance of the youth of the Slovak Republic in a group and interpersonal context], Mládež a spoločnost', 1(1), 14-31.

[20] Hargašová, M. (1996). Xenofóbia ako pojem a sociálny jav [Xenophobia as a concept and a social phenomenon], Mládež a spoločnost', 2(1), 63-71.

[21] Hinton, P. R. (2000). Stereotypes, cognition and culture: psychology focus. Philadelphia: Routledge.

[22] Hofreiter, L. (2002). K niektorým bezpečnostným rizikám Slovenskej republiky [On some security risks of the Slovak Republic], Krízový manažment, 1(1), 24-30. 
[23] Islam, M. R., \& Hewstone, M. (1993). Dimensions of contact as predictors of intergroup anxiety, perceived out-group variability, and out-group attitude: An integrative model. Personality and Social Psychology Bulletin, 19, 700-710. https://doi.org/10.1177/0146167293196005.

[24] Kamenec, I. (2005). Holokaust na Slovensku, jeho reflexie v literatúre a spoločnosti [The Holocaust in Slovakia, its reflections in literature and society]. In: Kolektív autorov. Terezínske listy: sborník památníku Terezin, (pp. 82-91). Praha: Oswald.

[25] Kerr P. \& Moy, P. (2002). Newspaper coverage of fundamentalist Christians. JournalismE Mass Communication Quarterly, 79, 54-72.

[26] Kobylarek, A. (2016). Preface: Levels of resentment in the University of the Third Age. Journal of Education Culture and Society, 7(1), 5-8. doi: 10.15503/jecs20161.5.8.

[27] Korherr, J. (1996). Pedagogická psychológia pre teológov [Educational psychology for theologians], Bratislava: RCBF UK.

[28] Králik, R., Lenovský, L., \& Pavlikova, M. (2018). A few comments on identity and culture of one ethnic minority in central Europe. European Journal of Science and Theology, 14(6), 63-76.

[29] Krivý, V. (2001). Hodnotové orientácie a náboženské prejavy slovenskej verejnosti v 90.rokoch [Value orientations and religious expressions of the Slovak public in the 1990s], Sociológia, 33(1), 7-45.

[30] Kugler, M. (2017). Výzvy, ktorým čelí náboženská sloboda v Európe [Challenges facing religious freedom in Europe]. In: Katolícka cirkev na Slovensku: Zborníky z konferencii. Retrieved January 10, 2021, from https://www.kbs.sk/obsah/sekcia/h/dokumenty-a-vyhlasenia/p/ zborniky-z-konferencii/c/bratislava-konferencia-ludske-prava-martin-kugler

[31] Kvasničková, A. (2005). Náboženstvo ako kolektívna pamät: prípad Slovenska a Čiech [Religion as a collective memory: the case of Slovakia and Czechia], Bratislava: Univerzita Komenského v Bratislave.

[32] Lajčáková, J., Gallová-Kriglerová, E., Kadlečíková, J., Balážová, Z., \&Chudžíková, A. (2017). Riešenie nezamestnanosti Rómov: Od mýtu k praxi a spät' [Addressing Gypsy Unemployment: From Myth to Practice and Back], Bratislava: Centrum pre výskum etnicity a kultúry, Skalica: Rómske advokačné a výskumné stredisko.

[33] Langmeier, J., \& Krejčiřová, D. (1998). Vývojová psychologie [Developmental psychology], Praha: Grada publishing.

[34] Leslie, A. M., Knobe, J., \&Cohen, A. (2006). Acting intentionally and the side-effect: Theory of mind and moral judgment. Psychological science, 17(5), 421-427.

[35] Mannheim, K. (2007). Problém generácií [The problem of generations], Sociální studia, 1-2, $11-44$.

[36] Marec, S. (2020). Hanbíš sa za svoju vieru? Nehanbi sa! [Are you ashamed of your faith? Do not be shy!] Retrieved January 15, 2021, from https://dennikn.sk/1892643/ hanbis-sa-za-svoju-vieru-nehanbi-sa/.

[37] Martín, J. G., Rojas, A. M., \& Králik, R. (2020). The problem of the 'individual' concept in the Kierkegaard's journals. European Journal of Science and Theology, 16(2), 39-46.

[38] Máhrik, T., Vasbieva, D. G., Králik, R., \& Kondrla, P. (2020). Salvation as the teleological vector in Kierkegaard's practice in christianity. European Journal of Science and Theology, 16(4), 43-52.

[39] Mesková, L. (2018). Cultural differences between the countries of Western Europe and the countries of the ancient Eastern Bloc. XLinguae, 11(1XL), 300-309. doi: 10.18355/ XL.2018.11.01XL.25.

[40] Mikulová, K. (2018). 12 spôsobov ako (NE) komunikovat' svoju vieru [12 ways to (NOT) communicate your faith]. Retrieved January 15, 2021, from https://blog.postoj. sk/37560/12-sposobov-ako-nekomunikovat-svoju-vieru.

[41] Ministerstvo kultúry SR, cirkevný odbor. (2017). Cirkvi a náboženské spoločnosti v roku 2017 [Churches and religious societies in 2017].Retrieved January 10, 2021, from internet: PDF.

[42] Ministerstvo vnútra SR. Koncepcia boja proti extrémizmu na roky 2011 - 2014: Príloha č. 5 - Schéma rámcového vymedzenia problematiky extrémizmu [Concept of the fight against extremism for the years 2011 - 2014: Annex no. 5 - Scheme of the framework definition of the issue of extremism]. Retrieved January 10, 2021, from www.minv.sk.

[43] Mutlu, S. (2020). Development of European consciousness in Erasmus students. Journal of Education Culture and Society, 2(2), 87-102. doi: 10.15503/jecs20112.87.102 
[44] Nadácia otvorenej spoločnosti, IUVENTA - Slovenský inštitút mládeže Ministerstva školstva vedy, výskumu a športu SR. Výlety Naslepo (hate speech, l'udsképráva): Slovník pojmov [Blind trips (hate speech, human rights): Glossary]. Retrieved January 15, 2021, from http:/ /osf.sk/ wp-content/uploads/2016/11/CVO_Jeden-svet-na-skolach_metodiky_str28-39.pdf

[45] Omeri, A., Malcolm, P., \&Ahern, M. (2003). Meeting the challenges of cultural diversity in the academic setting. Nurse Education in Practice, 3(1), 5-22. doi: 10.1016/S1471-5953(02)00026-4

[46] Pavlíková, M., \& Žalec, B. (2019). Struggle for the humanself and authenticity: Kierkegaard's critique of the public, established order, media, and false christianity. Bogoslovni Vestnik, 79(4), 1015-1026. doi: 10.34291/BV2019/04/Pavlikova

[47] Piaget, J., \& Inhelder, B. (1993). Psychológia dietáata [Child psychology], Bratislava: Sofa.

[48] Poláková, E. (2000). Výchova k tolerancii vovzdelávacom procese: Možnosti kultúrnej inštitúcie Múzea Židovskej kultúry privýchovemládeže k tolerancii [Education for tolerance in the educational process: possibilities of the cultural institution of the Museum of Jewish culture in the education of youth for tolerance], Acta Judaica Slovaca, 6(6), 211-223.

[49] Polonský, F., \& Novotný, J. (2011). The Level of Knowledge about Islam and Perception of Islam among Czech and Slovak University Students: Does Ignorance Determine Subjective Attitudes? Praha: Univerzita Karlova.

[50] Putman, R. \& Campbell, D. (2010). American grace: How religion divides and unites us. New York: Simon and Schuster.

[51] Roubalová, M., Králik, R., Slivka, D., \& Tavilla, I. (2018). The significance of bringing first fruits of the land into Jerusalem temple: A historical-theological perspective. Historia Ecclesiastica, 9(1), pp. 3-13.

[52] Rozhlas a televízia Slovenska [RTVS]. (2017). Život bez predsudkov. Rôznorodost'v nás a okolo nás [Life without prejudices. Diversity in us and around us].Retrieved January 16, 2021, from https://www.rtvs.sk/radio/archiv/11373/631407

[53] Rybak, O. S. (2018). Value Orientations of People Learning Toward Different Types of Culture: An Empirical Study. Journal of Education Culture and Society, 9(2), 11-23. doi: 10.15503/ jecs20182.11.23

[54] Sibley, Ch. G. \& Duckitt, J. (2008). Personality and Prejudice: A Meta-Analysis and Theoretical Review. Personality and Social Psychology Review, 12(3), 248-279. doi: 10.1177/1088868308319226

[55] Slivka, D. (2018). Hermeneutic relationship between personal and social ethics in Christian religious communities in the society. European Journal of Science and Theology, 14(5), 61-68.

[56] Slovenská academia vied[SAV].(1998). Náboženstvo 1998 [Religion 1998].Retrieved January 10, 2021, from http://sasd.sav.sk/sk/data_katalog_abs.php?id=sasd_1998001

[57] Sociologický ústav Slovenskej akadémie vied. (2000). Výskum európskych hodnôt 1999-2000: Názory, postoje a hodnoty obyvatelov Slovenska v európskom porovnaní [Research of European values 1999-2000: Opinions, attitudes and values of the population of Slovakia in European comparison]. Retrieved January 10, 2021, from http://www.sociologia.sav.sk/old/evs. $\mathrm{html}$

[58] Stephan, W. G., Stephan, C. W. (2000). An integrated threat theory of prejudice. In S. Oskamp (Ed.). Reducing prejudice and discrimination, (pp. 23-45). Mahwah, NJ: Erlbaum.

[59] Stockdale, M. S., \& Crosby, F. J. (2004). The psychology and management of workplace diversity. Oxford: Blackwell Publishing Ltd.

[60] Stríženec, M. (2001). Súčasná psychológia náboženstva [Contemporary psychology of religion]. Bratislava: Iris.

[61] Šišková, T. (1998). Výchova k toleranci a proti rasismu [Education for tolerance and against racism], Praha: Portál.

[62] Štatistický úrad Slovenskej republiky. Sč́tanie obyvatel'stva SR v r. 2001, 1991, 2011 [Census of the Slovak Republic in 2001, 1991, 2011]. Retrieved January 20, 2021, from http:// portal. statistics.sk/files/tab-15.pdf

[63] Tižík, M. (2006). K sociológii novej religiozity: Podoby zmeny náboženského života v 20. Storočí [On the sociology of the new religiosity: Forms of change in religious life in the 20th century], Bratislava: Univerzita Komenského.

[64] Tížik, M. (2011). NáboženstvovoverejnomživotenaSlovensku: zápasy o ideový character štátu a spoločnosti [Religion in publiclife in Slovakia: struggles for the ideologicalcharacter of the state and society], Bratislava: SociologickýústavSlovenskejakadémie vied. 
[65] Tolnayová, A. (2016). Vývin morálneho vedomia [Development of moral consciousness]. In: J. Husár, M. Machalová, T. Hangoniand B. Kuzyšin (Eds.), Nová sociálna edukácia človeka V. Medzinárodná interdisciplinárna vedecká konferencia, Prešov, 7. 11. 2016, (pp. 265-272). Prešov: Prešovská univerzita v Prešove.

[67] Vacek, P. (2008). Rozvoj morálního vědomiźákư [Development of students' moral consciousness], Praha: Portál.

[68] Valach, M. (2000). Filosofické kořeny intolerance [Philosophical roots of intolerance], Acta Judaica Slovaca, 6(6), 33-44.

[69] Valčo, M., Valčová, K., Kardis, K., \& Slivka, D. (2019). A prophetic critique of Samuel Štefan Osuský against Hitlerism, Fasism and War. Historia Ecclesiastica, 10(2), 179-192.

[70] Vašečka, M. (2009). O vzt́ahoch k iným a k sebe: O diverzite v krajine pod Tatrami [About relations with others and with oneself: About diversity in the country below the Tatras]. In: M. Bútora, M. Kollár, G. Mesežnikov and Z. Bútorová (Eds.), Kde sme? Mentálne mapy Slovenska, (pp. 241-260). Bratislava: Inštitút pre verejné otázky \& Kalligram.

[71] Vašečka, M. (2009). Postoje verejnosti k cudzincom a zahraničnej migrácii v Slovenskej republike [Public attitudes towards foreigners and foreign migration in the Slovak Republic], Bratislava: IOM.

[72] Vašečka, M. (2013). Sociologické aspekty xenofóbie [Sociological aspects of xenophobia]. In: O. Prostredník (Ed.), Cudzie nechceme, svoje si nedáme? Prekonávanie xenofóbie a antisemitizmu v náboženských textoch a praxi, (pp. 5-45). Bratislava: Univerzita Komenského v Bratislave.

[73] Vašečka, M., \& Koštál, C. (2009). Integrácia migrantov - vieme čo znamená? Politiky v Slovenskej republike $v$ komparatívnej perspektive [Integration of migrants - do we know what it means? Policies in the Slovak Republic in a comparative perspective], Bratislava: Inštitút pre dobre spravovanú spoločnost'.

[74] Vlach, J. (2006). Prenos hodnôt a medzigeneračné diferencie [Transfer of values and intergenerational differences], Bratislava: Univerzita Komenského.

[75] Vymetalova-Hrabakova, E., Kondrla, P., Vlasova, V. K., Dmitrichenkova, S. V., \& Pashanova, O. V. (2020) Human as the protector of creation. XLinguae, 13(3), 13-21.doi: 10.18355/ XL.2020.13.03.02

[76] WVS. Svetový výskum hodnôt 1998 [World Values Survey 1998].Retrieved January 15, 2021, from http:/ / sasd.sav.sk/sk/data_katalog_abs.php?id=sasd_1998002

[77] Žalec, B. \& Pavlíková, M. (2019). Civic virtues and functions of religion in public life. European Journal of Science and Theology, 15(6), 75-84.

[78] Žilínek, M. (1997). Étos a utváranie, mravnej identity osobnosti [Ethos and the formation of the moral identity of the personality], Bratislava: IRIS. 